\title{
Application of Customer Relationship Management (CRM) practices in Hotel Industries: A Review
}

\author{
Kanchan $^{1}$ and Dr. Aditi Sharma ${ }^{2}$ \\ ${ }^{1}$ Research Scholar, ${ }^{2}$ Assistant Professor \\ Department of Commerce,
}

Indira Gandhi University, Meerpur, Rewari, Haryana (India)

\begin{abstract}
Customer Relationship Management (CRM) established unlimited attention in recent business scenario. It is considered as a tool of resolution to enormous scope. Due to the competitive environment, CRM is crucial and becomes strength for any industry's performance. Though, limited efforts have done that reveals the relationship between CRM dimensions with service sector. Thus from Hotel Industry, the study helps to identify CRM practice in Hotel Industries for the future perspective of Customers and Hotels, yet it becomes easy and effective to build a long term relationship with customers. This paper assists not just to explain the affiliation, however also to clarify the supportive part of marketing abilities in this connection.
\end{abstract}

\section{Keywords}

Marketing capability, Hotel Industries, Dimensions, Customer Relationship Management (CRM)

\section{INTRODUCTION}

In current state about economical service world, improvement day by day regarding customer services is required. Today many business organizations like as Banks, Hotels, Telecommunications, Transportation, Insurance companies, Hospitals, Education and other service providers realize importance of CRM. They also appreciate the possibility of CRM that attract new customers and retain existing. With showing CRM the organization just wants to develop personal and expressive connections also for development of their business. CRM has just become one of the most debated issues and a core in the business field (Balaram and Adhikari, 2010; Becker et al., 2009). It is value stating that CRM is mainly based on the faith. CRM forming a sustainable relationship with customers and the basis for obtaining loyal customers who are much more money making than non -loyal ones (Dowling, 2002).There is cumulative usage of CRM in the service sector, but still very few researches are applied its disparity applications for momentous industry (Vogt, 2011). Besides, several studies are increasing their significance into CRM for the hotel industry (Akroush et al., 2011; Sadek et al., 2011; Sin et al., 2005). As a result of that, it is reasonable to prime the decision that it is not only very little consideration has been given to the CRM scopes in the hotel industry, but there is also quite of opportunity for spreading the literature about CRM scopes and hotel performance. Therefore, this paper gives relationship for filling the gap for the hotel industries.

\section{Literature Review}

It is successful observed that the concept of CRM can be defined in different ways. It also means different things to different people, depends on the working environment CRM has been used in organizations (Baran et al., 2008; Dimitriadis and Steven, 2008; Piskar and Faganel,2009).Though, to upsurge the literature nearby CRM, it is a planned approach that assists 
International Journal of BRIC Business Research (IJBBR) Volume 4, Number 1/2/3, August 2015

organizations to exercise inside possessions to accomplish the connection with customers for the entire of their survives series, in ordinance to create a viable benefit and recover an organization's concert". Even with the statistic that CRM carries durable assistances to organizations, as a unabridged enhancement proceeds since realizing it supplementary to others (Kotler, 2002; Mguyen et al., 2007). In addition to this, Gronroos (2004) stated about service organizations for their inherent characteristics of the production. It is of energetic status for it to inspire behavioral patterns of continuous improvement and to retain customers last longer. Therefore, obviously such aspiring objectives can be accomplished over executing CRM, which will give effect in forming prolific affiliation between organizations and their customers (Verdugo et al., 2009).

\subsection{CRM in Hotel Industries}

CRM is ideally suitable in the hotel industry, specifically when implementing it successfully and effectively, as hotels receive a lot of data about customers. these data can be converted into beneficial information about them (Kotler, 2002; Mguyen et al., 2007; Nasution and Mavondo, 2008).CRM model valuation was unhurried in numeral of methods, including customer satisfaction, market efficiency and monetary recital (Sin et al., 2005), customer performance and financial performance with customer retention and sales evolution. As economic records cannot offer sympathetic of CRM influence and result, therefore the total concert should be hired in appraisal of CRM results (Wu and Hung, 2007). Prevailing literature connects that the use of numerous procedures is appropriate to evaluate the influence of CRM on business performance is critical as it is a useful tool to provide in complexity understanding of initiative's total procedure performance (Wu and Lu, 2012; Wu and Hung, 2007).

\section{CRM Dimensions}

It is recognized that the multi proportions observation of CRM can be measured comparatively new, as of the only insufficient studies that are made on the CRM dimensions of service sectors (Akroush et al., 2011; Sadek et al., 2011; Sin et al., 2005). CRM consists of four ample behavioral dimensions (Sin et al., 2005; Yim et al., 2005).

These behavioral dimensions are:

(a) Customer Orientation

(b) CRM organizations

(c) Knowledge management

(d) Technology based CRM 


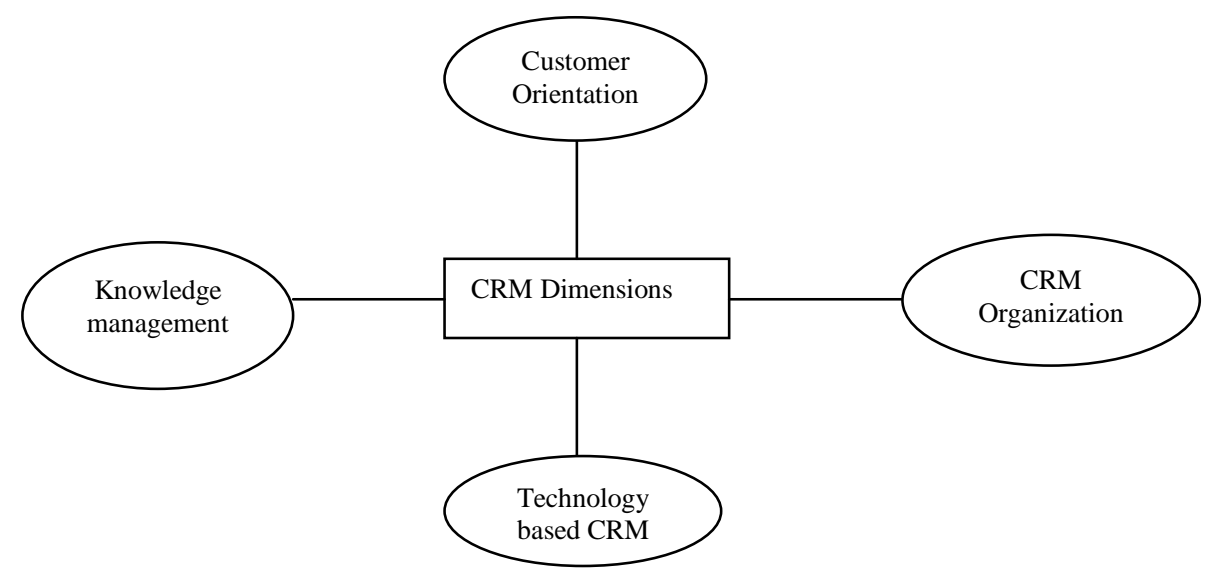

Figure1. CRM Dimensions

It is important that all of these dimensions can systematically work in society to pledge its enhanced performance (Sin et al., 2005; Yim et al., 2005). In this regard, Abdullateef et al. (2010) inquiry on the influence of CRM dimensions on call -centers in Malaysia and situations that customer orientation, as one of the CRM dimensions, is supplementary than key customer focus.Customer orientation as one of the most significant dimensions of CRM (e.g. Wang, Huang, Chen, and Lin, 2010). Also, numerous researchers highpoint the significant effects of leading studies on CRM dimensions in the hotel sector (Akroush et al., 2011; Sadek et al., 2011; Sin et al., 2005).

\subsection{Customer Orientation}

It is imperative in the first occurrence to check that the main determination behind customer oriented behaviors is to increase customer satisfaction and to form customer loyalty. Consequently numerous studies have predictable nearby good customer concerned with behaviors and certify extremely positive influence on its performance (Kim, 2008; Yilmaz et al., 2005).

As in the service concerned with organization, the service delivery in a hotel occurs when there is interaction between service providers and service encounter (Ki Lee et al., 2006). Therefore in order to enhance service experience, managers need to focus on customer interaction. Customer direction can be attained through a positive affiliation between customer and service provider. Research has reinforced that customer orientation leads to increase organizational performance. Moreover, customer alignment is also one of the market beneficial sources and hence it helps in delivering an appropriate plan to satisfy customer needs. Numerous studies revealed that there is a association between customer orientation and marketing planning competences.Consequently, the numerous positive impacts of customer orientation on organizations recital and the fact remnants that there is quiet a deficiency of literature about customer orientation influence on hotel performance (Sin et al., 2006; Tajeddini 2010).

\subsection{CRM Organization}

First and major, to improve service employees in customer oriented behaviors, organizations have to develop a suitable working atmosphere for service in work for providing staff with the current tools and technology, customer-satisfaction chasing and complaints management systems, inspiring leadership and applicable rewards systems. As a result of the previous supportive working circumstances, organizations can ensure the required customer oriented behaviors for their employees (Mechinda and Patterson, 2011). 
International Journal of BRIC Business Research (IJBBR) Volume 4, Number 1/2/3, August 2015

The success of CRM employment relies on the active contribution of the employees in the organization itself (Tamilarasan, 2011).Certainly, all the organization resources have to be included in order to implement CRM successfully and to improve organizations performance. Furthermore, Richards and Jones (2008) states that CRM may impact forthcoming marketing decisions, such as brand differentiation and price. In this regard, it has been reported that numerous hotel chains estimate their room prices deliberating to the customer data that were collected previously (Nunes and Dréze, 2006). Knowledge about customers acts a vital role in CRM, taking into our consideration that the main purpose behind collecting data about customers is to get a clear image about them from different perspectives (Sin et al., 2005). Consequently, organizations can authenticate such data to be talented to found and grow valuable association with their customers.

\subsection{Knowledge Management}

Expedient in sequence about customers can be gathered during interactions with them in the association itself and the decisive factor for decide whether CRM is victorious or not (Plessis and Boon, 2004; Stringfellow et al., 2004). Managing knowledge successfully can really help the organizations to have accomplishment in building better customer relationship, ensuing in a positive shock on organization recital. The achievement of relationship management is intensely reliant on collecting and analyzing customer in sequence. As a stuff of facts, it is essential for organizations to stay behind competitive and this aim cannot be achieved except they enjoy wide knowledge about their market and make use of their obtainable knowledge about their customers. Hence, Lo et al., (2010) recommend examining the influence of knowledge management dimension on hotel industry in future research. Fan and $\mathrm{Ku}$ (2010) selected that customer knowledge administration is resolutely connected with marketing capabilities and it really enables organizations to obtain tactical managerial decisions for humanizing their recital.

\subsection{Technology Based CRM}

Kasim and Minai (2009) find out that CRM technology dimensions are firmly related to hotel performance, as hotels requisite to use information technology for improving their performance. In this stare, new technologies are measured as the nucleus drivers for modification (Minghetti, 2003).

Besides, plentiful studies stated that the collision of information technology on association recital description concerning the optimistic role of information technology in CRM. In other words, these studies exposed that many customer centric strategies cannot achieve their goals, without the assistance of information technology (Eid, 2007; Ozgener and Iraz, 2006; Sigala, 2005; Sin et al., 2005; Yeh et al., 2010). Therefore, CRM based technology allows organizations to sketch and execute victorious marketing proceedings to retentive customers relations and making them additional profitable (Roberts, Liu, and Hazard, 2005). Moreover, Chang, Park and Chaiy (2010) established that CRM technology raises marketing capabilities by providing precious information regarding customers. Thus, this study is considered to elucidate the function of planning and marketing capabilities in the relationship between CRM dimensions and hotel performance. Furthermore, this study is also intended to be additional inclusive than the study of Chang et al. (2011), as it will inspect the mediating result of marketing capability among all dimension of $\mathrm{CRM}$, and hotel performance. 
International Journal of BRIC Business Research (IJBBR) Volume 4, Number 1/2/3, August 2015

\section{Discussion and Conclusion}

This study offers a model to express the firm relationship between CRM dimensions and hotel industries. It provides a inclusive framework that is useful for elucidation the blow of the CRM dimensions on hotel concert. It is conventional that the concept of customer relationship management has not been completely established and nor evaluated to resolve the potency of the affiliation between scope of CRM and hotel trade recital. Moreover, this study uniquely extends the body of information by explaining the theoretical possibilities of the mediating role of CRM dimensions and hotel performance. This paper will elevates consciousness amongst hotel managers to more attended regarding CRM dimensions and help them in improving hotel recital and competitiveness.

\section{ACKNOWLEDGEMENTS}

We would like to give our special thanks to editors and whole WSP team of publications for giving a platform of opportunity for researchers to develop their research. We will be pleased for obtaining valuable comments by the editor and reviewers.

\section{References}

Abdullateef, A.O., Mokhtar, S.S., Yusoff, R.Z. (2010), "The impact of CRM Dimensions on Call Center Performance", International Journal of Computer Science and Network Security, Vol.10,No.12, pp184195.

Asikhia, O. (2010), “Customer Orientation and Firm Performance among Nigerian Small and Medium Scale Businesses”, International Journal of Marketing Studies, Vol.2, No.1,pp197-213.

Balaram, A., Adhikari, B. (2010), "Managing Customer Relationships in Service Organizations",Administration and Management Review,Vol.21,No.2, pp 65-78.

Brohman, M.K., Richard, T.W, Piccoli, G., Parasuraman, A. (2003), "Data Completeness: A Key to Effective Net-Based Customer Service Systems”, Communications of the ACM, Vol.46,No.6, pp 47-51.

Chang, W., Park, E.J., Chaiy, S. (2010), "How does CRM technology transform into organizational performance? A mediating role of marketing capability", Journal of Business Research,Vol.63, pp 849855.

Chaudhry, P. E. (2007), "Developing a process to enhance customer relationship management for small entrepreneurial businesses in the service sector", Journal of Research in Marketing and Entrepreneurship, Vol.9, pp 4-23.

Cizmar, S., Weber, S. (2000), "Marketing effectiveness of the hotel industry in Croatia", International Journal of Hospitality Management, Vol.19, No.3,pp 227-240.

Dutu, C., Halmajan, H. (2011), "The Effect of Organizational Readiness on CRM and Business Performance", International Journal of Computers, Vol.1, No.2,pp 106-114.

Gronroos, C. (2004), "The relationship marketing process: communication, interaction, dialogue, value", Journal of Business and Industrial Marketing, Vol.19, No.2,pp 99-113.

Kasim, A., Minai, B. (2009), "Linking CRM strategy, customer performance measure and performance in hotel industry", International Journal of Economics and Management, Vol.3,No.2, pp 297 - 316. 
International Journal of BRIC Business Research (IJBBR) Volume 4, Number 1/2/3, August 2015

Kim, W.G., Lee, Y-K., Yoo, Y-J. (2006), "Predictors of relationship quality and relationship outcomes in luxury restaurants". Journal of Hospitality and Tourism Research, Vol.3,No.2, pp 43-69.

Piskar, F., Faganel, A. (2009), "A Successful CRM Implementation Project in a Service Company:Case Study”, Journal of Management, Informatics and Human Resources, Vol.42,No.5, pp 199-208.

Robinson, L., Jr, Neeley, S. E., and Williamson, K.(2011). "Implementing service recovery through customer relationship management: Identifying the antecedents", Journal of Services Marketing, Vol.25, pp 90-100.

Singh B., Grover S. and Singh V. (2015), “Application of Different Techniques used in Service Industries”, Proceeding of twelfth AIMS International Conference, IIM Kozhikode, pp.1930-1934.

Tajeddini, K. (2010), "Effect of customer orientation and entrepreneurial orientation on innovativeness: Evidence from the hotel industry in Switzerland", Tourism Management, Vol.31,No.2, pp 221-231.

Verma , S., Chaundhuri, R. (2009), "Effect of CRM on Customer Satisfaction in Service Sector in India", Journal of Marketing and Communication,Vol.5, No.2, pp55-69. 